\title{
Laços e desenlaces entre criação e reflexão crítica no teatro português contemporâneo
}

\author{
Maria João Brilhante
}

\section{Sobre pensamento e ação}

I screver sobre a relação entre criação e reflexão crítica implica revisitar, num primeiro momento, os conceitos de teoria e prática e a sua incontornável convivência, para em seguida olhar o teatro português contemporâneo a partir deste tema.

Entendemos por teoria um conjunto de regras ou leis mais ou menos sistematizadas, aplicadas a uma área específica e também o conhecimento especulativo, metódico e organizado de caráter hipotético e sintético. Quanto a prática, ela consiste na ação ou no fato de agir. A definição de dicionário refere também que se trata do que é real, do que não é criação teórica, mas sim execução de algo que se planeou. Diznos ainda que, desde os Gregos, teoria e prática se opõem, tendo a primeira características estritamente especulativas, desinteressadas e abstratas por estar virada para a contemplação da realidade, em oposição à prática e a qualquer saber técnico aplicado.

$\mathrm{Na}$ verdade, a teoria enquanto conhecimento sistemático deve estar fundamentada em observações empíricas e postulados racionais de onde decorre a formulação de leis e categorias gerais que permitam eventualmente a transformação dos fatos e das realidades da natureza.

No campo específico do teatro, a teoria consiste no conjunto de concepções sistematicamente organizadas e aplicadas à obra teatral e na explicação ou análise da sua natureza. A primeira que conhecemos com estas características é, como sabemos, a Poética de Aristóteles.

Dito isto, parece legítimo perguntar se subjacente às várias dicotomias assinaladas - real vs abstrato, sistemático vs casual, especulativo vs ativo - não é possível reconhecer na teoria uma dimensão prática, no sentido de que pressupõe a ação de pensar da mesma forma que parece ser possível considerar a práxis como um pensamento em ação.

Gostaria, pois, de defender que criação é pensamento em ação e que a separação entre teoria e prática no campo da criação artística pertence a um conjunto de outras dicotomias que têm vindo a ser questionadas pela arte contemporânea como seja a oposição entre obra e processo contestada pela "performance art" e pelas artes performativas nas quais o teatro tem o seu lugar.

Maria João Brilhante é professora da Faculdade de Letras da Universidade de Lisboa. 
Ao longo dos tempos, não foram raros aqueles para quem criação no teatro se fez como ato de pensar um novo teatro. Creio que um caso extremo, e por isso mais fascinante e ainda hoje estimulante, será o de Artaud. O que caracteriza a teoria artaudiana é que, considerada como ação e criação, ela foi mais eficaz e consequente do que as suas produções teatrais. Podemos, é claro, dizer que só a efemeridade destas últimas nos permite fazer uma tal afirmação. Creio, todavia, que o discurso teórico é, em Artaud, uma verdadeira cena mental, habitada por ações e nela reside a sua pulsão criativa. Poderia ainda referir outros exemplos que, de modos diferentes, realizam a indissociabilidade entre teoria e prática, criação e reflexão crítica. Em Brecht, por exemplo, encontramos um pensamento crítico que se processa em várias dimensões, entre as quais a criação teatral e que conduz à própria interpelação do real, estando nesse real contido o teatro como arte e instrumento de transformação/ação. A prática brechtiana é, portanto, contínua sistematização de ideias e conceitos em regras que configuram uma teoria para um teatro épico.

O teatro é ação e reflexão, tal como a teoria o é. Quando a criação teatral põe em evidência a sua dimensão reflexiva podemos dizer que atinge plena realização e tem repercussões na comunidade e na própria arte. Por isso, quando alguns artistas, que reconhecemos como alicerces teóricos do teatro contemporâneo, tais como Gordon Craig, Appia, Copeau, Meyerhold entre outros, produziram as suas criações não as separaram da produção de pensamento crítico, dessa forma confirmando e fazendo avançar as etapas de implantação de um teatro novo. Ao assumirem para si o papel de analistas e críticos que o campo teatral não lhes conferia, privando-os de voz ativa sobre a natureza da criação, estavam a abrir caminho ao que seria décadas mais tarde - anos 60 - o modo de intervenção de criadores que decidem ocupar o território da crítica para lhe conferirem um papel de resistência à teorização e à crítica com origem na Academia. Como veremos, interrogando mas também alimentando alguns lugares-comuns, a reflexão crítica produzida pelos artistas parece querer impor uma dimensão literal e instrumental ao pensamento sobre a criação, desta forma afirmando a condição material, concreta e transitória dessa mesma criação, assim questionar a maneira como a teoria crítica dela se aproxima e afasta como pretexto para desenhar e reivindicar o seu próprio território.

\section{História de uma relação}

Apreciar a história da relação mal resolvida entre teoria e criação teatral desviar-me-ia do meu objetivo central. Farei, por isso, considerações breves sobre este assunto em jeito de antecâmara à análise da relação tal como ela se vem construindo no espaço teatral português contemporâneo.

Em primeiro lugar há que notar a ancestral desconfiança dos artistas no que toca ao conhecimento que teóricos e críticos possam ter do fenômeno teatral. Não "conhecer o peso dos projetores”, como afirmou Jean Vilar, é manifestamente um óbice à compreensão da natureza do teatro, o que sustenta outros lugares-comuns tidos como inquestionáveis pelos criadores, como sejam a primazia do ofício sobre a formação acadêmica no treino do ator, a valorização da sensibilidade do artista em detrimento da sua inteligência ou cultura ou ainda o caráter transcendente e marginal da criação artística que a coloca acima de circunstâncias profissionais ou mercantis. Um século, pelo menos, de embate abriu poucas brechas num muro de que a história do teatro dá amplos testemunhos e de que me ocorre, para não ser indiscreta acerca dos nossos contemporâneos, dar o exemplo de Corneille, fornecedor de textos para o teatro do Marais, discutindo com os doutrinários da tragédia clássica Chapelain e d'Aubignac: de um lado a defesa do saber fazer e das exigências artísticas da cena sustentando uma visão do mundo barroca, de outro a novel autoridade dos teó- 
ricos produtores de regras de composição dramática que visavam transpor para a cena um desenho racionalizado do mundo.

$\mathrm{Se}$, como dizia antes, o século XX, porventura aquele que promoveu a teoria e a reflexão crítica ao seu expoente máximo, irradiando a partir de França alguns dos discursos mais influentes da cultura ocidental e fazendo da semiótica e do estruturalismo teorias passe para a interpretação da obra teatral, não conseguiu inverter este mau relacionamento entre artistas e teóricos, mal grado alguns avanços na interpenetração dos seus universos, isso deve-se em parte à persistente hegemonia do modelo linguístico e do logocentrismo no modo como o teatro foi sendo abordado e entendido. Que o teatro "não passa todo por palavras", como escreveu Osório Mateus, quer se trate da sua prática quer da sua interpretação, já o sabemos. A reivindicação, feita pelos artistas, bem cedo no século passado, de uma especificidade do teatro associada à sua dimensão não-verbal, plástica, performativa foi-se fazendo ouvir e foi ganhando espaço em práticas classificadas como vanguardistas, mas os críticos encartados e os teóricos nas academias pouca atenção concediam às diversas formas de criação que ora expulsavam a palavra, ora a submetiam a um tratamento de choque, materializada, perdendo o seu caráter instrumental de espelho do mundo e de veiculadora de sentido.

A dificuldade que os semiólogos, a partir do final dos anos 50, manifestaram em reconhecer nestas práticas uma voz em diálogo com a teoria e em abandonar o paradigma linguístico para pensar criaçooes onde a produção de sentido está disseminada pelas diversas linguagens e por vezes subalternizada por um processo de criação que valoriza a auto-referencialidade, levou a uma ruptura que a "performance art" tornou óbvia. Hoje permanece um mal-estar que os numerosos estudos em torno de conceitos como teatralidade, visualidade, performatividade produzidos pela Academia não logram, apesar de tudo, sanar completamente.

Atitudes de deliberada literalização do discurso sobre o teatro, como a que relata Shanon Jackson ${ }^{1}$ na sua obra Professing Performance a propósito do modo como alguns criadores falam das suas produções, são vistas com desconfiança ou desprezo por alguns teóricos das artes do espetáculo e constituem, sem dúvida, tomadas de posição dos artistas contra o que consideram ser o relativismo das análises críticas, a opacidade dos discursos especulativos, a aplicação de um jargão teórico com o consequente fechamento desses discursos dentro do círculo de entendidos. A alegada distância dos acadêmicos em relação ao processo de criação, tal como muitos dos referidos juízos acerca do exercício de reflexão crítica correspondem, sem dúvida, a uma visão simplista, mas também a uma luta pela conquista de uma posição hegemônica no campo teatral prosseguida por certos criadores. Difícil é reconhecer que o lugar de onde se cria ou aquele de onde se fala da criação não são coincidentes nem nunca serão, que a ação de pensar e a de criar alimentam e alimentam-se de um contexto sociocultural e que existe mútua dependência entre prática teatral e teoria do teatro pela simples razão de que a primeira resiste à efemeridade e se expande através da segunda e que esta não existe sem o estímulo permanente das concretizaçôes singulares para construir os seus modelos e os aferir no terreno.

Quando os criadores sentem necessidade de teorizar - lembremos os casos de Artaud ou Peter Brook, mas também, repito, daqueles que inscrevem nas suas criações uma dimensão autocrítica ou meta teatral - não fazem mais do que concretizar um ato de pensar - segundo dife-

1 Shanon Jackson, 2004, Professing Performance. Theatre in the Academy from Philology to Performativity, Cambridge: Cambridge University Press. 
rentes modalidades ou linguagens - o seu processo criativo no quadro mais vasto de ideias de teatro sempre plurais, transitórias, mas historicamente situadas.

Este gesto não é específico da contemporaneidade; encontramo-lo no passado, se bem que ele reflita hoje a consciência daquilo a que Kaprow chamou, nos anos $60^{2}$, o "creator-asauthority", ou seja, consciência da intervenção ativa do artista no espaço da teoria e da reflexão crítica, quer em torno de criações artísticas (os objetos), quer do ato de criar (os processos). Invadindo o território do crítico, o artista como crítico não só desafia a autoridade deste, como põe igualmente em causa certas assunções acerca do objeto artístico e do seu fazer, obrigando à revisão de convenções que procuram tornar a criação artística compreensível.

O que ocorre neste confronto entre autoridades é uma diferença de posição do crítico ou teórico e do artista face ao quadro de ideias de teatro com o qual se relacionam objetos e criaçôes artísticas. Retirando do conhecimento desse quadro e da capacidade de o convocar para a reflexão crítica a sua "expertise", o crítico constrói sobre isso a sua autoridade; pelo contrário, $o$ artista pretende retirar desse quadro de referências (dessa formação discursiva) a legitimação da sua arte; pretende fazer recair sobre a própria obra o exercício de reconhecimento e interpretação da rede de citações em aberto que a compōem ou radicalizar a sua posição acerca da irrelevância de atribuir sentido a uma obra cujo sentido reside na sua própria existência como tal.

Esta relação mal resolvida, talvez devesse levar o crítico ou estudioso do teatro a centrar o seu olhar nas opções tomadas pelos artistas e que conduziram à configuração das suas obras, procurando mostrar que efeitos essas opçōes produzem e que ideias de teatro se expóem através dessas opções. Quando há uns meses atrás, o Teatro da Cornucópia, em Lisboa, resolveu pôr em cena o Construtor Solness de Ibsen, optou por realizar uma desconstrução cenográfica da cena realista, dando a ver pedaços de um interior burguês repletos de sinais de teatro (portas que abriam colocadas de forma a deixar ver a entrada em cena dos atores, fazendo-os atravessar com algum ruído o palco, p. exemplo, criando palcos sobre o palco vazio etc.). Ao mesmo tempo, optava pelo realismo no jogo dos atores, aqui e ali introduzindo alguns traços de estilização, numa mesma lógica de contraste que nos sinaliza a presença do exercício de pensar o teatro burguês realista em simultâneo com o ato de criar o espetáculo.

Dito isto, a crescente aproximação da crítica e da teoria a questôes centrais da prática teatral como sejam o trabalho criativo do ator (Josette Féral), o lugar do espectador como coprodutor do evento teatral (W. Sauter), a representação contemporânea dos textos clássicos, a dimensão performativa do teatro como prática cultural (Fischer-Lichte), a questionação das categorias do modo dramático no teatro contemporâneo (Lehman), a re-teatralização do teatro (teatro de imagens de Bonnie Marranca), entre outros aspectos, revela o longo caminho percorrido desde que o texto dramático constituía o núcleo de uma ideia de teatro hegemônica no ocidente. A abertura a formas teatrais de outras culturas bem como a proliferação de criaçôes conjugando várias linguagens artísticas e conferindo à dimensão plástica e material do espetáculo um papel central, contribuíram para o deslocamento do olhar do crítico e do teórico.

\section{Lugares de encontro}

Numa abordagem da relação entre criação e reflexão crítica importa também perceber quais os lugares onde elas se cruzam, onde se insinuam os diálogos possíveis e não apenas as disputas de

2 Allan Kaprow, "The Artist as a Man of the World", Essays on the Blurring of Art and Life, Berkeley: University of California Press, p. 55, citado por Shannon Jackson, p. 135. 
que antes falei. Alguns desses lugares são as escolas, as companhias de teatro, as publicaçóes impressas e on-line, os fóruns de discussão especializada, ou os espaços de criação mais informais.

Fiz há pouco referência ao arraigado lugar-comum, pelo menos em certas paragens, e falo essencialmente de Portugal, que pretende opor a formação do ator, do cenógrafo ou do encenador em exercício, chamemos-lhe assim, à formação nas escolas de teatro. A escola é, em certos discursos e situaçôes informais, apresentada como insuficiente transmissora de saber fazer, embora noutros casos seja valorizada precisamente por possibilitar a imersão numa confluência de discursos teóricos e críticos sobre a arte do teatro oriundos de mestres cujas práticas artísticas fundadas nesses discursos sustentam credibilizam a sua pedagogia. Nas escolas profissionais (Conservatórios, Escolas de Arte Dramática), mas também em Universidades que preparam para a profissão e não apenas para a investigaçáo, a presença de estudiosos do teatro é, por vezes, tão discreta que o exercício reflexivo por eles proposto surge em desvantagem na competição pela atenção e energia pedidas aos estudantes. Dito de outro modo, persuadir alunos, que são solicitados para desenvolver e incorporar formas e técnicas de ação, a que exercitem uma reflexão em torno da sua própria aprendizagem prática ou a propósito da criação contemporânea, afinal de contas, aquela que lhes fornece parâmetros e modelos para as suas próprias práticas, torna-se um difícil empreendimento

Apesar disso a escola é, seguramente, um dos locais privilegiados para que esse cruzamento entre criação e reflexão crítica seja realizado com melhores resultados, isto é, com benefícios para a mútua relação do fazer e do pensar e acima de tudo, para que a teoria ou a crítica sejam implicadas na criação. Quando, normalmente no espaço da formação avançada, a investigação permite ao artista construir um projeto em articulação com a reflexão teórica ou crítica, a academia está a desempenhar o seu papel, acolhendo e promovendo esse encontro. Da mesma forma, o fato de ser possível ao estudioso do teatro acompanhar por dentro a criação, construindo a cada momento instrumentos teóricos que nascem da sua colaboração é uma experiência que, por certo alguns já viveram e que faz nascer uma cumplicidade emocionante com os criadores. Neste caso a partilha do espaço-tempo da criação permite inquirir em tempo real o processo, as opções e sua fundamentação. Por vezes, o cruzamento de que venho falando dá-se ainda quando alguns criadores convocam para seu redor pessoas com a função de promoverem um trabalho de interrogação dos modelos, das linguagens, partilhando essa reflexão crítica com a criação.

Também através da publicação em papel ou online se tem alargado o espaço de cruzamento entre criadores e estudiosos do teatro e do espetáculo. Esse espaço, tradicionalmente ocupado pelos discursos acadêmicos, ciosos da sua autoridade, foi invadido pelo paradigma "cultural" e pelo novo historicismo (Stephen Greenblatt) que impuseram, nas duas últimas décadas, a abordagem interdisciplinar e trouxeram a criação contemporânea para o centro da reflexão crítica.

É claro que coexistem diferentes tradições nesta viragem "culturalista" e que a França procurou resistir à vaga anglo-saxônica, de alguma forma reinventando modos de entretecer teoria e criação inscritos na linhagem de semiólogos como Barthes, Dort, Ubersfeld ou no primeiro Pavis, e de criadores como Antoine Vitez, Jean Pierre Vincent, Patrice Chéreau. Mas, basta visitar "sites" e publicações eletrônicas para perceber como neles se dá conta de propostas de criaçōes fortemente ancoradas numa conceitualização que faz explodir o campo teórico nos finais do século XX e desafia a "arrumação" para fins pedagógicos que encontramos nos manuais de teoria e crítica do teatro e do espetáculo em torno de correntes tais como: estudos de gênero, psicanálise, marxismo e materialismo, desconstrucionismo, teoria da recepção, pós-modernismo e pós-colonialismo.

São cada vez em maior número, os performers que propõem para discussão os seus tra- 
balhos em encontros científicos habitualmente reservados a universitários e que fazem desse tempo-lugar comum, um espaço de trabalho à vista de criadores e teóricos.

\section{0 caso português}

Em Portugal, circunstâncias históricas e políticas particulares exigem alguma cautela na transposição do quadro e das linhas que acabo de traçar. O fechamento ao mundo provocado por mais de 40 anos de ditadura e de exercício da censura teve consequências que justificam o que hoje é a relação entre criação e reflexão crítica.

Está por fazer de uma forma sistemática o recenseamento e o estudo da produção crítica avulsa, por vezes não identificada, espalhada em periódicos, programas de espetáculos, ou mesmo daquela que compilada pelos próprios críticos e estudiosos, carece de um enquadramento histórico e ideológico que esclareça as suas coordenadas. Casos como os de Jorge de Faria e Eduardo Scarlatti, de João Pedro de Andrade, de Redondo Júnior, de Jorge de Sena, de Urbano Tavares Rodrigues e de Carlos Porto ${ }^{3}$ são reveladores de uma atenção regular à criação teatral, que se exerceu fora das Universidades, embora não completamente à margem do paradigma literário.

A Universidade, onde o teatro foi abordado através da literatura dramática e estudado à margem da realidade teatral profissional, desenvolveu, nos anos 50 e 60, um espaço de criação com os estudantes ${ }^{4}$ que permitiu alguma abertura a formas teatrais introduzidas em Portugal por artistas com perspectivas radicalmente opostas às que vigoravam então no país e até noutros países da Europa. Figuras como Adolfo Gutkin, Luís de Lima, Victor Garcia, entre outros, ignoraram a censura e a polícia política (PIDE) com o beneplácito da Fundação Gulbenkian aliás, e criaram espetáculos/eventos irrepetíveis que se propagaram como ondas para fora das Universidades.

Até há bem pouco tempo, cabia aos historiadores de teatro registrar a contribuição do discurso crítico e teórico para uma compreensão da criação teatral. Um deles, Luiz Francisco Rebello, colecionando uma prodigiosa massa de informação e tendo acompanhado exaustivamente a produção dramatúrgica (sendo ele próprio dramaturgo) e a atividade teatral desde finais dos anos 30, fez assentar a sua história do teatro português nas características literárias, temáticas e ideológicas das peças de teatro produzidas, bem como nos movimentos e correntes artísticas que permitem, em parte, explicar as opçōes de repertório das companhias e o arraigado ascendente do teatro realista-naturalista nos principais palcos portugueses até ao final da II Guerra Mundial. Isolado da Europa, o país falhara o encontro com as experiências vanguardistas da $1^{\text {a }}$ metade do século XX, com a exceção pouco consequente do simbolismo de Pessoa e do futurismo de Almada Negreiros. As pálidas tentativas de escapar a essa estética dominante na dramaturgia e mais raramente ainda na criação cênica foram ignoradas ou rejeitadas tanto pelo público elitista, como pela crítica.

A dificuldade de sobreviver às contingências políticas (materializadas na censura) e a dependência total da bilheteira e do circuito comercial acarretavam um permanente desvirtuar dos programas artísticos das companhias de atores que se foram constituindo no pós-guerra (al-

3 Carlos Porto era o decano dos críticos de teatro e faleceu precisamente durante o Congresso da ABRACE.

4 Barata, José Oliveira, 2009, Máscaras da Utopia. História do Teatro Universitário em Portugal, Lisboa: Fundação Calouste Gulbenkian. 
gumas tentaram divulgá-los quando da sua constituição) $)^{5}$ e reduziram o desejo de fazer teatro a uma prioridade que pouco espaço deixava à produção de pensamento crítico e ainda menos à experimentação de novas formas teatrais.

Apesar de pontuais tentativas no sentido de conquistar espaço para a reflexão crítica e para a produção teórica, quer entre intelectuais, quer entre artistas, são poucas as obras que de forma explícita e programática, ou seja, transcendendo a intervenção circunstancial, muitas vezes usada como gesto político, foram sendo tornadas públicas. O Pequeno tratado de encenação de António Pedro, artista plástico, poeta surrealista, dramaturgo e fundador e encenador do Teatro Experimental do Porto (anos 50) é uma exceção, por se tratar de um objeto curioso, que continua a ser manual de procedimentos para aprendizes de encenação, como era desígnio do seu autor ao pensar na transformação da prática teatral sua contemporânea, mas por ser igualmente discurso programático de um encenador que pensou o teatro como arte plástica e deixou disso testemunho escrito.

Nos anos 70, a universidade portuguesa abre-se timidamente à semiologia e ao estruturalismo, surgindo algumas tentativas para refletir criticamente o teatro em trabalhos acadêmicos ou nos jornais e revistas. Disso é testemunho a obra Escrita de Teatro reunindo em 1977, textos escritos nessa década, por Osório Mateus, professor, crítico e encenador, constituindo um interessante caso de confluência do trabalho de escrita com a produção teatral que ele desenvolveu até 1989

Com a revolução de Abril, de novo se fez sentir a urgência de fazer teatro, de pôr em cena os textos e os autores proibidos, de ganhar um público que se afastara das salas de teatro e que os mais jovens criadores mal conheciam, de afirmar diferenças estéticas e artísticas para concretizar sonhos de teatro adiados, pouco espaço deixando para a reflexão. No entanto, em poucos outros momentos da história do teatro em Portugal foi tão intensa a liberdade de experimentar modelos e formas de produção à margem das rotinas de criação teatral e foi tão radical e apaixonado o discurso crítico sobre esse teatro.

Se a partir dos anos 90 ocorreu uma viragem no relacionamento entre artistas e estudiosos do teatro, proporcionando uma diferente abordagem da criação teatral e uma lenta integração do discurso crítico e teórico no espaço artístico isso deveu-se essencialmente a três fatores:

(i) A criação por Osório Mateus na Faculdade de Letras da Universidade de Lisboa de estudos pós-graduados e de um centro de investigação (Centro de Estudos de Teatro) que promoveu, desde a sua constituiçáo em 1992, uma relação próxima com artistas e companhias. Através da construção e disponibilização na internet de uma base de dados sobre espetáculos produzidos em Portugal no século XX (CETBase) se foi aí criando uma rede de utilizadores, muitos deles artistas que contribuem eles próprios para a sua atualização.

A partir dessa base estão a surgir estudos monográficos identificando os diversos vetores da atividade teatral e propondo a sua análise e interpretação com o contributo de disciplinas tais como a economia, as ciências sociais, a história das ideias, os estudos de gênero etc. Percursos artísticos de companhias, de encenadores e atores ganham uma coerência insuspeitada agora que investigadores mais jovens refletem criticamente sobre eles. Estes estudos poderão mesmo vir a ser responsáveis por uma resposta por parte dos criadores, confrontados pela pri-

5 Duas publicaçôes recentes ajudam a traçar a história de duas destas companhias: Tito Lívio, 2009, Teatro Moderno de Lisboa (1961-1965) Um marco na História do Teatro Português, Lisboa: Caminho; Rui Pina Coelho, Casa da Comédia (1946-1975) Um palco para uma ideia de teatro, Lisboa: Imprensa Nacional-Casa da Moeda (col. temas portugueses). 
meira vez com análises que aspiram, pela sua sistematicidade e fundamentação teórica a devolver a esses criadores uma imagem da sua prática artística.

Esta aproximação tem sido feita com cautela, precisamente porque o passado de censura e autoritarismo foi responsável pelo fechamento dos artistas à discussão. Vêm recentemente integrando fóruns de discussão nas Universidades ou noutras instituiçōes para falar das suas atividades ou de temáticas com elas relacionadas. Da mesma forma, é cada vez mais frequente a colaboração entre estudiosos e artistas, cabendo aos primeiros trabalho de dramaturgia, de tradução, de assistência de encenaçãa, de pesquisa e de escrita. Os caminhos estão abertos, resta trilhá-los e perceber como articular práticas distintas que têm em comum a arte do teatro.

(ii) Um segundo aspecto diz respeito à necessidade que se foi fazendo sentir de criar espaços de publicação de estudos quer pontuais, quer de maior fôlego, o que impulsionou, por exemplo, o aparecimento de revistas especializadas - os Cadernos de Almada, a Adágio, a revista do Observatório de Actividades Culturais (OAC), a Sinais de Cena, a Revista dos Artistas Unidos, a Obscena também em versão eletrôni$\mathrm{ca}$ - algumas delas ligadas a instituições do Estado como foi o caso da revista Teatro escrito(s) publicada pelo então Instituto das Artes do $\mathrm{Mi}$ nistério da Cultura, entretanto interrompida.

A dificuldade em dar continuidade à publicação destas revistas prende-se com a fragilidade do campo teatral em Portugal no que diz respeito ao reduzido número de leitores e à má distribuição de publicações especializadas, assim como ao número ainda não significativo de agentes preparados para assegurar regularmente e com rigor o estudo da criação teatral contemporânea ou do passado.

(iii) Finalmente, um terceiro aspecto veio reconfigurar a relação entre criação e reflexão crítica. Tratou-se da emergência nessa última década do séc. XX no campo artístico (teatro, mas também dança, performance e artes plásticas) de um importante número de jovens cria- dores que romperam com a herança marcada pelo passado de censura e repressão, bem como pelo isolamento cultural, a qual determinou as opções de repertório, mas sobretudo estéticas e até de funcionamento artístico-laboral tomadas no teatro em Portugal no período pós-revolução. Estes jovens (Lúcia Sigalho, Monica Calle, João Garcia Miguel, Miguel Moreira, Carlos Pessoa) situavam-se num espaço aberto, global, sem fronteiras, especialmente as que derivavam de ideias de teatro, politizadas, da geração do chamado teatro independente. A sua visão era cosmopolita e encontravam afinidades eletivas mais rapidamente noutras paragens do que na sua cidade. Para tal contribuiu a entrada de Portugal na Comunidade Europeia, a facilidade de circulação entre criações e criadores, sobretudo no espaço europeu e graças à internet. $\mathrm{O}$ que pode, creio, singularizá-los é a interessante ligação que procuraram estabelecer entre o quadro global das referências artísticas que dominam e a perspectiva muito pessoal através da qual problematizam o seu lugar no mundo. As suas criações desafiam e interrogam a situação sempre precária e em permanente refeitura da sua ação no campo teatral.

\section{A atualidade da reflexão e da prática}

Década e meia após a Revolução e a explosão das mais variadas formações teatrais, bem como a inevitável conquista e hegemonia do território por parte de algumas delas - Comuna, Cornucópia, Cendrev, Companhia de Teatro de Almada, Novo Grupo, Teatro o Bando - os anos 90 fazem, portanto, nascer essa nova geração armada de um imperioso desejo de "matar o pai" na figura do encenador/diretor consagrado e aparentemente detentor de poder, ou de subverter as regras de criação, impondo produçôes híbridas, onde o texto dramático deixou de estar no centro, recusando representar o mundo ou transmitir uma mensagem política, inscrevendo nessas produções uma "pulsão" conceitual, nem sempre bem compreendida. 
É este o historial sobre que assenta o atual teatro feito em Portugal e que explica, por um lado maior atenção dos artistas à ação dos teóricos e críticos e destes à criação que acontece à sua volta, e por outro a expansão do ato de refletir criticamente no interior da própria criação.

Todos eles foram e são adeptos da performance, do teatro site specific, da improvisação e da nova dramaturgia pós-dramática, de uma recusa da auto-complacência na relação com a sociedade e com os públicos, procurando, às vezes desastradamente, a provocação.

Geração perdida nas malhas de uma sociedade neo-liberal que desconfia de excessos, depois daquilo que considera terem sido os exageros libertários do pós-revolução, é também uma geração sacrificada para que uma outra lhe sucedesse. Os que hoje tentam concretizar os seus projetos de criação já não alimentam ilusões, são mais pragmáticos nas suas pretensões e aprenderam a pensar com menos generosidade e como uma questão de sobrevivência as suas investidas num território do teatro cada vez sujeito a maiores limites. Entre vários exemplos que poderia apresentar destaco os Visões Úteis (e as suas produções site specific na cidade do Porto), o teatro Praga (que baseia na improvisação o seu trabalho, raramente partindo de textos ou desconstruindo-os através da sua "recriação" cênica), o Teatro Bruto, As Boas Raparigas vão para o céu as más para parte alguma, o Teatro do Vestido, os Primeiros Sintomas, os Cão Solteiro e muitos outros "coletivos" cujos elementos constitutivos vão inclusivamente participando nas produções uns dos outros, partilhando espaços, trabalho e recursos. É também diferente a sua relação com o discurso crítico e teórico, já que são cada vez mais fluidas as fronteiras entre os que fazem e os que pensam, e também porque eles próprios alimen- tam um circuito de reflexão, mesmo se marginal, que funciona não raras vezes como meio de legitimação da sua criação. Estão conscientes de que o seu trabalho criativo tem de se escudar num pensamento contemporâneo para o qual contribuem.

Dois dos casos mais interessantes e a merecerem uma reflexão crítica sistematizada para a qual deixo aqui algumas pistas são os percursos dos Artistas Unidos e do Karnart.

Este último, construído em torno de um artista chamado Luís Castro e do conceito que desenvolveu de Perfinst (performance+instalação) tem vindo a conquistar um lugar sólido no campo teatral português, apesar de sérias dificuldades relacionadas com a obtenção de um espaço fixo para desenvolver a sua atividade.

O que torna o trabalho do Karnart digno de nota é a consistência do seu programa e a persistência com que desenvolve uma reflexão em ato do quadro conceptual em que labora. Luís Castro cria instalaçõos inspiradas em universos marginais, habitados por violência latente e repressão nas quais integra açõos performativas onde performers manipulam/animam espaços e objetos da instalação.

$\mathrm{Na}$ verdade, da mesma forma que acompanhamos o percurso de um artista plástico e vamos descobrindo o trabalho de repetição e transformação de motivos, temas, técnicas, procedimentos e opções estéticas, também no caso da criaçôes do Karnart reencontramos, transformados e recontextualizados, objetos, temas, e figurações que povoam o imaginário de Luís Castro. A liberdade que assiste ao observador de uma obra plástica é aqui, todavia, negada ao espectador da Perfinst porque esta conta com a sua participação.

Aliás, um dos aspectos curiosos destas criaçóes consiste no encontro entre o especta-

6 Ver sobre estas questôes vejam-se as obras de Vera Borges, 2001, Todos ao palco!' Estudos sociológicos sobre o Teatro em Portugal, Oeiras: Celta e 2007, O Mundo do Teatro em Portugal. Profissão de actor, organizaçôes e mercado de trabalho, Lisboa, Imprensa de Ciências Sociais. 
dor e a dimensão textual que a Perfinst também integra (textos de Santareno, Lorca, Camus, Kafka, Copi foram alguns dos pontos de partida da sua criação). Desde logo o título da performance revela a operação de transposição e condensação da qual resulta: por exemplo, os textos o Equívoco de Camus e Yerma de Lorca estão em Equerma, uma performance apresentada no Teatro Nacional D. Maria II em 2006, na qual um espaço central do palco apresenta cenas do texto de Camus, enquanto em torno desse espaço estão expositores cujos objetos (universos humanos em miniatura) são manipulados pelos performers ao som (por vezes gravado) de excertos do texto de Lorca. A montagem das ações, realizada por Luís Castro, manipula a percepção do espectador que é convidado a, no final, observar a instalação como obra de arte.

Numa das mais recentes produções chamada Visōes sobre Cemitério de pianos, a partir do romance Cemitério de pianos de José Luís Peixoto, o texto era objeto de um trabalho mais intenso de construção por parte do espectador ao longo do seu percurso pelas várias salas da Escola de Medicina Veterinária ocupadas pela Perfinst. Uma gravação de um excerto do texto introduzia-nos no espaço-tempo da instalação e da performance que a animava, mas apenas como leitmotiv e antes de nos serem apresentadas por uma performer-guia as regras de funcionamento da instalação e o papel previsto para o espectador. Um gabinete de curiosidades constituía a primeira sala onde o universo criado no romance era concretizado através de objetos em miniatura vindos de um passado já só existente em lojas de ferro velho e antiquários, assiduamente visitados, aliás, por Luís Castro. A partir daí começava uma viagem que podia ser aleatória não havendo qualquer tipo de continuidade entre os temas das salas e não tendo os espectadores o mesmo conhecimento do romance. Todavia, através de estímulos sonoros e da própria movimentação/deslocação dos performers, recriada cada noite, o espectador era atraído para onde existia ação, ou seguia um guião entregue à entrada, jogando-se com a variabilidade de cada noite e com o seu caráter único e irrepetível.

O projeto artístico de Luís Castro e do Karnart é singular e exemplar quanto a mim desse processo de reflexão e teorização implícitas na criação. Que ele se tenha tornado num desafio à reflexão e interpretação por parte da comunidade de artistas e espectadores é revelador do interesse deste work in progress e do conceito de arte performativa que lhe está subjacente.

Quanto aos Artistas Unidos, criados em 1995 em torno de Jorge Silva Melo, ator, encenador, realizador de cinema, e co-fundador do Teatro da Cornucópia, o próprio nome dado ao grupo exprime a ideia que subjaz ao trabalho aí desenvolvido, inspirando-se na designação da primeira produtora cinematográfica criada apenas por atores em Hollywood - a United Artists.

A fundação do grupo aconteceu na sequência de um projeto de escrita coletiva e produção de um espetáculo, tendo como ponto de partida um guião cinematográfico de Silva Melo, intitulado António, um rapaz de Lisboa, que acabou por se tornar filme anos mais tarde. A apresentação no auditório da Fundação Calouste Gulbenkian, após meses de trabalho num barracão na margem sul do rio Tejo, local onde, aliás, parte da ação da peça decorre, constituiu um acontecimento no panorama teatral português. De um só gesto, uma diferente maneira de criar um espetáculo surgia e um texto que falava da atualidade portuguesa numa linguagem que captava a fala da praça pública desarrumada, excessiva, "suja", por vezes incompreensível - era o centro de uma criação sem cenários e sem "encenação".

Mais de uma dezena de atores muito jovens e uma veterana, Lia Gama, construíam um fresco ao vivo da sociedade portuguesa. Atravessavam o palco como transeuntes da cidade de Lisboa, gente que vai e vem do trabalho, detendo-se por momentos à nossa frente para mostrar episódios, quadros da sua vida anônima, dos 
seus problemas e afliçóes (a doença, a pobreza) das suas fraquezas (a droga), dos seus desejos (uma viagem turística a Espanha), das dificuldades (de relacionamento na família, na cidade). Possuído por um ritmo vertiginoso, com a ajuda de algumas cadeiras, uma cama e muita roupa usada, o espetáculo criava fragmentos do mundo, mas não representava um mundo organizado, e apesar de falar de Lisboa continha todas as metrópoles. Exemplo de um teatro pósdramático que começava a invadir, como vimos, a criação portuguesa contemporânea, ganhava aqui uma amplitude que advinha do próprio processo de criação e se tornou traço distintivo dos Artistas Unidos. Baseou-se na recusa da figura autoritária do encenador, no privilégio concedido ao teatro da palavra contra um teatro da decoraçáo e na centralidade do ator como criador. Nestes treze anos, o grupo foi concretizando um teatro político, isto é, um teatro da polis, que é reverberação da cidade, do que nela acontece e afeta a vida das pessoas. Para poder sê-lo, é preciso que os que integram o grupo os atores - sejam livres e responsáveis pelo seu trabalho artístico, sejam membros da cidade no teatro. O lema "Sem Deus nem Chefe" sob o qual foram organizados vários ateliers de escrita e respectiva produção de espetáculos, foi bem mais do que um slogan político: constituiu-se como princípio ou conceito a interiorizar na prática do grupo.

Apesar da direção artística caber a Jorge Silva Melo, os atores vêm produzindo espetáculos, por vezes sem assinatura de um encenador. Noutros casos, coreógrafos ou realizadores de cinema são convidados a dirigirem as produções e, desde sempre, escritores apresentam os seus textos produzidos pelos atores do grupo.

Os textos, como disse, são o ponto de partida das criaçóes dos Artistas Unidos e um dos fundamentos do seu projeto artístico. Têm sido apresentados ciclos que dão a conhecer a escrita contemporânea de autores estrangeiros (escoceses, irlandeses, dos países nórdicos, italianos, espanhóis, franceses...) ou são feitas enco- mendas a autores portugueses que escrevem, com os atores da companhia, num processo original que fora iniciado pelo próprio Silva Melo com António, um rapaz de Lisboa, O Fim ou tende misericórdia de nós, Prometeu - rascunhos à luz do dia e que recentemente deu origem a uma iniciativa de escrita à qual ironicamente o grupo chamou "Isto não é um concurso".

Mas é em torno da liberdade criativa do ator no teatro e da sua responsabilidade cívica que se estabelecem os laços mais firmes entre criação e reflexão crítica no percurso dos Artistas Unidos e do seu fundador. Através das suas crônicas em jornais, de breves ensaios reunidos posteriormente em livro (Deixar a vida, Século passado) ou de palestras (na Culturgest, em 2007), Silva Melo tem vindo a construir o discurso de uma prática ao ponto de ser provavelmente um dos poucos artistas em Portugal a exprimir verbalmente uma teoria original do ator e a praticar o que, simultaneamente, pensa sobre escrita de textos contemporâneos de teatro e sobre criação.

Antes de fechar este percurso com as palavras, escritas em 1998, de Jorge Silva Melo sobre o feliz encontro entre o gesto criador do ator e o olhar do diretor, gostaria de chamar a atenção para a complexidade do campo do teatro, de que os seus estudos são uma parte e de que este meu discurso é ainda uma ínfima parte. São muitas as instâncias que compóem esse campo e de que mal falei: o mercado, as instituições públicas e privadas, os media, os públicos, os organismos e grupos não oficiais e informais etc. Existem em complexa relação e em permanente negociação, para me servir da terminologia de Bourdieu. $\mathrm{O}$ que aqui pretendi traçar foi apenas uma amostra desse movimento de enlace e desenlace que tem caracterizado as relaçõos entre criação e reflexão crítica e partir daí para o espaço do teatro em Portugal.

Foi um dos momentos mais felizes de todo o meu trabalho: de novo o Miguel Borges iniciava um gesto fundador ao qual os outros 
atores, com segurança e delicadeza, com real inteligência prática, reagiam, respondiam, ecoavam. Era o quinto dia de ensaios de uma produção complexa e incerta e este jogo havia de ser determinante para todo o trabalho
- não apenas cenográfico. Todo o espetáculo haveria, depois, de se organizar sobre estes dilemas do revela/esconde, do encobre/descobre que um ator, numa tarde de luz interior, propôs. E eu consegui "ver".

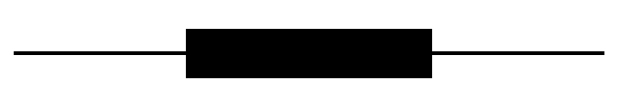

\section{Referências bibliográficas}

CARLSON, Marvin. Performance a critical introduction. London and New York: Routledge, 2004. FORTIER, Mark. Theory/Theatre an Introduction. London and New York: Routledge, 1997.

GOLDBERG, RoseLee. Performance Art from Futurism to the Present, London: Thames and Hudson, 1999.

JACKSON, Shannon. Professing Performance. Theatre in the Academy from Philology to Performativity, Cambridge: Cambridge University Press, 2004.

SHEPHERD, Simon \& WALLIS, Mick. Drama/Theatre/Performance, London and New York: Routledge, Col. The New Critical Idiom, 2004.

RESUMO: Através deste ensaio pretende-se recensear algumas formas de encontro/desencontro entre a criação teatral e a reflexão teórica em Portugal na contemporaneidade, assinalando-se contingências históricas e políticas que as foram determinando, ao mesmo tempo em que se defende o princípio da "reflexão em ato" para entender as relações entre teoria e prática no campo artístico. PALAVRAS-CHAVE: teoria do teatro português; teatro português contemporâneo; teoria e prática do teatro.

Jorge Silva Melo, 1998, “Ser dirigido pelos actores", Intensificação. Theaterschrift extra, Dez., p. 81. 